\title{
Eternal verities, eternal questions
}

\section{How our ancestors reconciled themselves to eternal life}

\section{Ben Bova}

$\mathrm{t}$ is difficult for us to understand the controversy that was caused early in the twenty-first century by the advent of human immortality. When, in the late 1990s, the Geron Corporation of California and the University of Texas Southwestern Medical Center announced that they had 'immortalized' human cell cultures, the general public hardly took any notice.

But when the Fossel Clinic in Michigan began demonstrating conclusively that ageing cannot only be stopped but actually reversed - when elderly patients were obviously rejuvenated and returned to the physical condition of thirty-year-olds - the groundswell of enthusiasm and controversy began to shake the world.

Today, we are quite accustomed to the fact that any man or woman can live as long as he or she desires - barring accident and remain physically youthful and active indefinitely.

Yet when the first successes of the Fossel Clinic brought that prospect of physical immortality to the full attention of the news media and the general public, great objections were raised and great fears were expressed.

Some feared that only the rich would be able to obtain immortality treatments, and this would lead to a widening and permanent gap between rich and poor. The infamous Death League fomented riots in dozens of cities around the world with their accusations that a wealthy and powerful élite would receive immortality treatments, while the poor and powerless would not be able to afford them.

Misguided though such accusations were, they attracted wide popular support and led to the creation of public committees to oversee the equitable distribution of immortality treatments. Others objected on religious grounds, firm in their belief that attempts to extend the human lifespan were attempts to subvert God's chosen plan. Although the most conservative religious believers firmly rejected immortality treatments for themselves (and, sadly, often for their families), the general public eagerly sought physical immortality.

Theologians then began to ponder the implications of this startling new capability. Many considered, like earlier Church fathers, that any new human faculty can only be attributed to God's beneficence. Some even claimed that Christ's exhortation, "Be ye therefore perfect, even as your Father which is in heaven is perfect," should be interpreted as referring to physical perfection, as well as moral.

Pope Michael I set the example for many Roman Catholics when he accepted the immortality treatment for himself, while at the same time resigning his position as Pontiff. "No man should remain in such a position of power indefinitely," he wrote in his famous encyclical, Vitam aeternam. His moral stance led to widespread public insistence that all political office-holders be subjected to strict limitations on their terms of office.

Pragmatists feared the economic and social dislocations that might accompany immortality, and pointed out that if the death rate were lowered almost to zero, then the birth rate must be equally lowered, or the world would suffer a population explosion of intolerable proportions. Despite these objections, and despite organized political campaigns against immortality (and some terrorist acts, such as the missile attack on the Fossel Clinic), once the general populace understood that death could be postponed indefinitely, an enormous groundswell of public pressure forced governments to abandon all thoughts of suppressing the scientific knowledge or of banning the immortality treatments altogether.

It turned out that the various therapies involved in 'immortalization' were much less expensive than the pessimists predicted. Basically, they consisted of injections of human growth hormones and a cocktail of enzymes such as telomerase. While the research leading to these capabilities was costly, it was largely funded by governmental tax revenues. Because of this, the real costs of clinical treatments were in fact kept far lower than health economists had expected more akin to a vaccination than an organ transplant.

The great struggle to adapt society to the greatly extended human lifespan took more than a century, however. Virtually every aspect of social, economic and political life underwent a fundamental change once the dread aspect of death had been thus removed to a distant horizon.

Humanity showed its resilience, in time. Birth rates around the world are very close to death rates now. Global population growth is stabilizing — not without a struggle, but a stable world population is in sight. Today, the birth of a baby is a cause for celebration by the entire community. Couples no longer have children to please their parents, or to gain some perceived advantage in their community. Babies are rare, and cherished.

The advent of immortality has brought an unexpected additional benefit. For all of history, humans have thought the stars were utterly unreachable. Even with modern space technology, it would take centuries to reach the nearest stars. Now, we have centuries to spend. Today the ships bearing the families of scientific explorers are heading out beyond the fringes of the solar system, plying the long, silent pathways to the stars, bearing the seeds of humankind into a waiting Universe.

Ben Bova is the author of more than ninety novels and works of nonfiction. Among the latter is Immortality: How Science Is Extending Your Lifespan - and Changing the World. He has been Executive Editor of both Omniand Analog Science Fiction magazine. He is President Emeritus of the National Space Society and a past president of Science Fiction Writers of America.

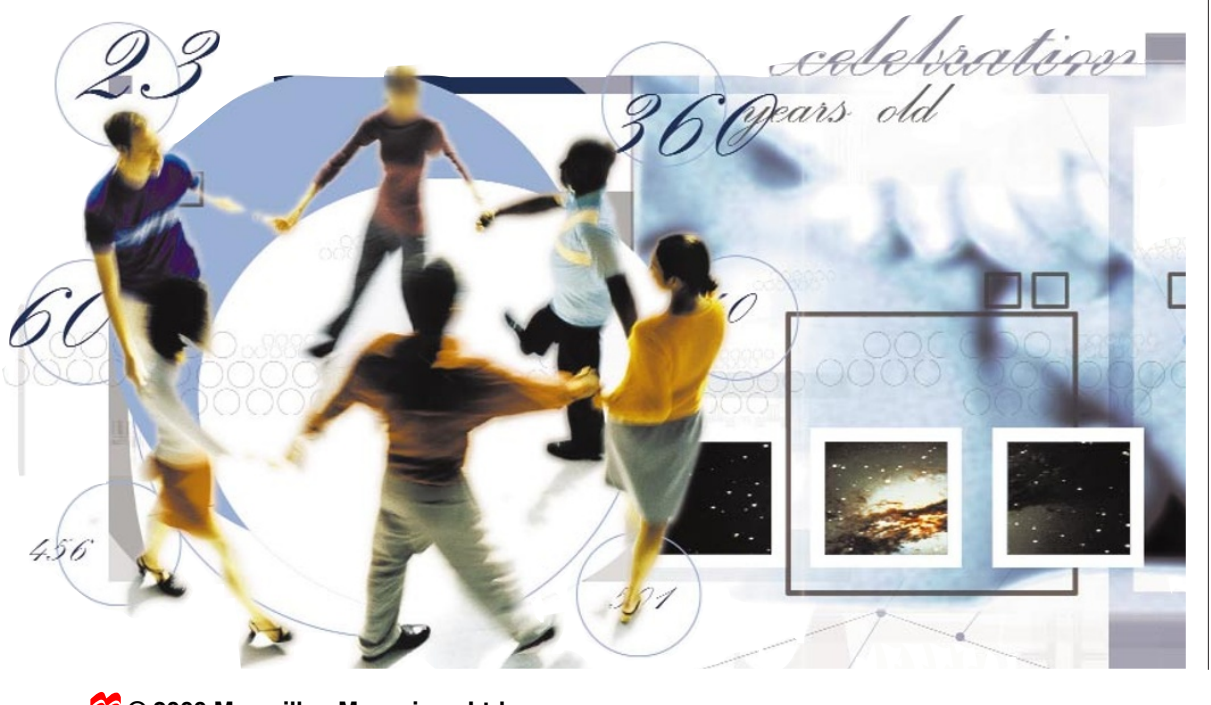

